\title{
Çalışanların Duygusal Emek Düzeylerinin Bazı Demografik Değişkenler Açısından Incelenmesi ${ }^{I}$
}

\author{
Investıgatıng The Emotional Labor Levels of Employees in Terms of Some \\ Demographic Variables
}

Hüseyin ASLAN*

Ibrahim Sani MERT $T^{* *}$

\section{$\ddot{O} Z$}

Bu çalışmanın amacı demografik değişkenlerin çalışanların duygusal emek kullanım düzeylerine olan etkisi belirlenmeye çalışmaktır. Bu amaçla Gaziantep, Adana ve Osmaniye illerindeki dört ve beş yıldızlı otellerde çalışan 549 kişiden anket yöntemi ile veri toplanmıştır. Verilerin analizi neticesinde yaş, cinsiyet, işletmedeki pozisyon, toplam çalışma süresi ve sektör tecrübesinin duygusal emek kullanım düzeylerine göre anlamlı farklılıklar gösterdiği tespit edilmiştir.

\section{ANAHTAR KELIMELER}

Duygusal Emek, Yaş, Cinsiyet, Sektör Tecrübesi

\begin{abstract}
The purpose of this study is to determine the effect of the intended demographic variables on the levels of emotional labor use of the employees. For this purpose, 549 participants working in four and five star hotels in Gaziantep, Adana and Osmaniye were collected by questionnaire method. As a result of the analysis of the data, it was determined that age, gender, occupation position, total working time and sector experience showed significant differences according to emotional labor utilization levels.
\end{abstract}

KEYWORDS

Emotioanl labor, Age, Gender, Sector Experience

\begin{tabular}{|c|c|c|}
\hline \multicolumn{2}{|c|}{ Makale Geliş Tarihi /Submission Date } & Makale Kabul Tarihi / Date of Acceptance \\
13.10 .2018 & \multicolumn{3}{c|}{\begin{tabular}{c}
31.10 .2019 \\
\hline \multirow{3}{*}{ Atıf }
\end{tabular}} & $\begin{array}{l}\text { Aslan, H. ve Mert İ.S. (2019).Çalışanların Duygusal Emek Düzeylerinin Bazı Demografik Değişkenler Açısından } \\
\text { İncelenmesi. Selçuk Üniversitesi Sosyal Bilimler Meslek Yüksekokulu Dergisi, 22 (2), 713-728. }\end{array}$ \\
\hline
\end{tabular}

\footnotetext{
${ }^{1}$ Bu çalışma, "Duygusal Emek İle İşe Yabancılaşma İlişkisinde Psikolojik Sermayenin Etkisi: Otel İşletmelerinde Bir Alan Araştırması” adlı doktora tezinden üretilmiştir

${ }^{*}$ Dr. Öğr.Üyesi, Osmaniye Korkut Ata Üniversitesi, huseyinaslan111 @ gmail.com, ORCID: 0000-0002-0547-1317

${ }^{* *}$ Prof.Dr., Antalya Bilim Üniversitesi, sanimert@gmail.com, ORCID 0000-0002-2850-1865
} 


\section{GİRIŞ}

Bir duygu yönetim süreci olan duygusal emek, çalışanların duygularını önceden belirlenmiş kurallara göre denetleyerek müşteriye sunması olarak tanımlanmıştır (Hochschild, 1983:7). Duygusal emek, sergilenen duygularla gerçekte hissedilen duygular arasındaki ilişkiye bağlı olarak çalışanlar üzerinde bazı olumlu veya olumsuz etkiler yaratabilmektedir (Dursun ve diğ., 2011). Duygusal emek kavramının yaratabileceği bu etkiler kavramın ilk defa Hochschild (1983) tarafından kullanıldığı tarihten itibaren bugüne kadar pek çok alanda araştırma konusu olmuştur.

Türkiye ve dünyada 2000'li yılların ikinci yarısından itibaren duygusal emeğin; tükenmişlik (Grandey, 2003; Brotheridge ve Grandey, 2002; Kim, 2008; Kruml ve Geddes, 2000; Martinez ve diğ., 2007), işten ayrılma niyeti (Cote ve Morgan, 2002; Chau ve diğ., 2009; Goodwin ve diğ., 2011), örgütsel vatandaşlık davranış1 (Beğenirbaş ve Meydan, 2012), iş tatmini (Grandey, 2000; Seery ve Corrigall, 2009; Ghalandari ve Jogh, 2012) iş performansı (Beğenirbaş ve Çalışkan, 2014) gibi farklı değişkenlerle olan ilişkisi incelenmiş, ancak demografik değişkenlerin (yaş, cinsiyet, sektör tecrübesi, çalışma süresi ve işletmedeki pozisyon vb.) duygusal emek kullanım düzeyi üzerindeki etkisi (Erickson, 2005; Cheung ve Tang, 2010; Dahling ve Perez, 2010; Wharton ve Erickson, 1993) literatürde sınırlı sayıda araştırılmıştır.

$\mathrm{Bu}$ önemden hareketle bazı demografik değişkenlerin çalışanların duygusal emek kullanım düzeylerine olan etkisi belirlenmeye çalışılmış ve araştırma yoğun bir şekilde müşteri ile etkileşim içerisinde bulunulan hizmet sektörü işletmelerinden olan otel işletmelerinde istihdam edilen çalışanların katılımı ile gerçekleşmiştir.

\section{KURAMSAL ÇERÇEVE}

\subsection{Duygusal Emek}

İlk olarak 1979-1983 yıllarında Arlie Russell Hochschild tarafindan kullanılan duygusal emek kavramı, Hochschild'in 1983 yilında The Managed Heart: Commercialization of Human Feeling kitabinda, Delta Havayolları'nın hostes eğitim merkezindeki kurslara katılarak, hosteslerin duygusal emek süreçlerinin incelenmesiyle gündeme gelmiştir.

Hochschild The Managed Heart kitabında mesleki ortamlarda sergilenen duyguların kurumsal olarak belirlenmiş tutumları ürettiğine ilişkin açıklamalar getirmiştir. Hochschild bu eserinde duygusal emeği, "dışarıdan gözlemlenebilecek yüz ve beden hareketlerini oluşturmak için duyguların yönetilmesini ifade eden" bir iş türü olarak tanımlamıştır (Hochschild, 1983: 7). Burada insanların diğer bir kişide belirli bir duygusal durum yaratmak için kendi duygularını yönetmeleri durumuna dikkat çekilmektedir (Wharton, 1993). Hochschild'e göre hizmet ilişkileri esnasında bireylerin uygun duygusal tepkiler geliştirmesine yönelik ortak beklentiler bulunmaktadır (Hochschild, 1983). Örneğin genel olarak kabin görevlilerinin neşeli ve cana yakın olması, cenaze görevlilerinin ise, tören sırasında hüzünlü ve sessiz bir görüntü içinde olması beklenmektedir (Ashforth ve Humphrey, 1993). Yani duygusal emek, çalışanların duygu gösterimlerini duruma uygun hale getirebilmek için duygularını abartması, uydurması ya da bastırması anlamına gelmektedir (Grandey, 2000: 94).

Hochschild (1983)'e göre, duygusal emek fiziksel emeğe çok benzer; yani "hizmet işinin” ya da sürekli etkileşimin söz konusu olduğu çoğu sektörde emek para karşılığı satılır. Genel olarak göz önünde yapılan bir eyleme dönüşür; yani işverenler tarafindan resmen mesleki bir gereklilik olarak talep ve "kontrol" edildiğinde, normal şartlarda özel olarak gerçekleşen duygu yönetimi alanından çıkıp kendiliğinden kamuya açık hale gelir ve artık işletme tarafından talep edilen duygu gösterim kurallarına göre sergilenir.

İşletme tarafından talep edilen duyguların çalışanlar tarafından nasıl sergileneceğini düzenleyen kurallar olarak tanımlanan (Morris ve Feldman, 1996: 987) gösterim kuralları ise tipik olarak toplumsal, mesleki ve örgütsel normlardan kaynaklanır ve duyguların ne zaman ve nasıl ifade edileceğini belirten kurallardır. Büyük oranda reçetelenmiş veya örtük olarak teşvik edilebilen gösterim kuralları, etkileşimleri yönlendirir ve duygusal ifadelerin sıklığını, yoğunluğunu, süresini ve çeşitliliğini etkiler (Ashforth ve Humphrey, 1993: 89). Açık gösterim kuralları, uygun duygular ve duygusal ifade ile ilgili somut olarak iletilen kurallara işaret eder. Mesela, "sıcak bir gülümseme ile hizmet veriyoruz" gibi bir iş tanımı veya şirket misyonunun yazılı beyanatı ile olabilir. Örtülü görüntüleme kuralları ise, toplumsal veya kurumsal normlar yoluyla iletilen yazılı olmayan kurallardır (Buckner, 2012: 29).

\subsubsection{Yüzeysel Davranıș (Yüzeysel Rol Yapma)}

Yüzeysel davranış, çalışanların hissetmiş oldukları duygudan kopmadan, ifadelerin değiştirilmesi anlamına gelmektedir (Hochschild, 1983). Yüzeysel davranışta çalışan, hissedilen gerçek duyguyu bastırıp gerçek duygudan kopmadan örgütün istemiş olduğu gösterim kurallarına göre duygularını düzenlemektedir (Asforth 
ve Humprey, 1993; Grandey, 2000; Brotheridge ve Grandey, 2002). Duygusal emek davranış1 sergilemenin bu stratejisinde, gerçek manada hissedilmeyen duyguların hissediliyormuş gibi yapılması söz konusudur. Bunu başarmanın yolu ise, mimik, jest ya da ses tonu gibi sözlü ya da sözlü olmayan ifadeleri dikkatli bir biçimde kullanmaktan geçer (Ashforth ve Humphrey, 1993: 92). Bu süreç, maske takmak ya da duyguları hissediyormuş gibi yapmak olarak da nitelendirilmiştir (Ashforth ve Humphrey, 1993). Örneğin bir otelin resepsiyonun da çalışan kişi kendini kötü hissetse de gülümseyebilir ve müşteriyi neşeli bir biçimde karşılayabilir. $\mathrm{Bu}$ durumda resepsiyon görevlisi aslında deneyimlemediği duyguları yansıtmaktadır (Hochschild, 1993).

Yüzeysel davranışta çalışanlar, rol yapma tekniğini kullanarak duyguların dışarıya yansıyış biçimini değiştirmektedir. Düşük omuzlar, eğik baş ya da sarkık dudaklar gibi yüz ya da beden hareketlerini değiştirmek yoluyla içsel hisler uyumlu bir hale dönüştürülebilir (Hochschild, 1993). Hochschild, çalışanların içsel duyguların değiştirmeden dışarıya yansıtılmasını kabin görevlileriyle yaptığı çalışmada bir kabin görevlisinin yüzeysel davranış sergileme yönteminin cana yakın davranışlar sergilemesi konusunda kendisine nasıl yardımc1 olduğunu şöyle anlatmıştır: "İyi hissediyormuş gibi yaptığım durumlarda bazen gerçekten neşeleniyor ve cana yakın hissediyorum. Yolcu bana gerçekten cana yakınmışım gibi yanıt veriyor ve ben de daha fazla cana yakın biçimde tepki veriyorum." (Hochschild, 1990: 121). Burada kabin görevlisi gerçekte hissetmediği bir duyguyu (cana yakınlık) ifade edebilmek için yüzeysel davranış metodunu kullanmaktadır. O halde yüzeysel davranış sergileme hissedilen ve gösterilen duygu arasındaki uyumsuzluk şeklinde ifade edilebilir (Ashforth ve Humphrey, 1993).

\subsubsection{Derinlemesine Davranış (Derinden Rol Yapma)}

Derinlemesine davranış, çalışanın gösterilmesi gereken duyguları işin gerektirdiği biçimde yansıtabilmek için kendi gerçek hislerini değiştirmesi sürecidir (Hochschild, 1983). Hochschild bu kavramı açıklamak için duygu yönetimi ve duygusal iş terimlerini de kullanmıştır. Derinlemesine davranış "bir duygu ya da hissin seviye ya da niteliğini değiştirmeye çalışma eylemi”dir (Hochschild, 1979: 561).

Hissedilen duygunun değiştirilmeye çalışılması süreci, derinlemesine davranış sergilemenin doğuracağ1 sonuçlardan çok bir duyguyu yaratmak ya da ifade etmek için harcanan çaba ya da yönetim eylemi üzerine odaklıdır. Hochschild (1983)'e göre, derinlemesine davranış sergilemenin iki yolu bulunmaktadır. Bunlardan birincisi, bir duyguyu aktif bir biçimde kontrol etmeye çalışmaktır. Burada duygular uyarılarak uyandırılıp davranışlara dönüştürülür. İkincisi ise duyguların eğitilmesidir. Burada ise, çalışanın ifade edilecek duygu ile ilişkili hatıra ya da imgeleri düşünme sürecidir. Örneğin, uçuş görevlileri yolcuların kendi evlerinde ağırladıkları misafirler olduklarını düşünmeye ya da böyle can sıkıcı davranmalarına sebebiyet verecek kötü olayları yaşamış olduklarını hayal etmeye çalışarak yolculara bu doğrultuda davranış sergileyebilirler (Hochschild, 1983).

Derinlemesine davranışın, yüzeysel davranıştan farkı direk duygulara odaklanması ve duyguları değiştirmek için çaba harcanmasıdır (Yang ve Chang, 2008: 881). Derinlemesine davranışta duygular içeriden değişirken, yüzeysel davranışta dışarıdan değişir (Chu, 2002: 19). Yüzeysel davranışta duygular değişmeden kalır ve çalışan hissediyormuş gibi davranırken, derinlemesine davranışta duygular değişir ve çalışan bu duyguların değişmesini ister. Derinlemesine davranışta çalışan daha önceki yaşadığı veya tecrübe ettiği bir duyguyla içinde bulunduğu duyguyu bütünleştirerek etkileşimde bulunduğu kişiye empati yaparak davranış sergiler (Schmidt ve Diestel, 2014: 1453).

\subsubsection{Samimi Davranış (Duyguların Doğal Yollarla İfadesi)}

Ashforth ve Humprey (1993)'e göre, samimi davranış; hizmet esnasında çalışanların sergilemiş oldukları davranışları gerçekten hissederek sergiledikleri davranışlardır. Ashforth ve Humprey (1993)'e göre, Hochschild çalışanların kendiliğinden gerçekleşen veya doğal deneyimlerle sergilemiş oldukları davranışları göz ardı etmektedir. Hochschild'e göre çalışanlar kendiliğinden oluşan duygular için ekstra bir çaba sarf etmektedir (Anderson, 2014: 21). Morris ve Feldman (1996)'da çalışanların örgütün istediği davranışları yaşıyor olsalar bile bu davranışları örgütün istediği davranışlarla örtüştürmek için çaba harcamak zorunda olduklarını belirtmiştir. Ashforth ve Humprey (1993) ve Diefendorff ve diğ. (2005) ise, çalışanların herhangi bir çaba harcamadan ve gerçekten hissettikleri belirli davranışlar sergileyebileceklerini ifade etmektedir.

Yüzeysel davranış ve derin davranıştan farklı olarak herhangi bir şekilde rol yapmayı gerektirmeyen samimi davranış (Bağc1, 2015: 75), doğal duygularla örtüşen bir davranıştır (Chu ve Murrmann, 2006: 1182). Yüzeysel davranış ve derinlemesine davranış sergileme, hislerin bilinçli ve stratejik olarak manipüle edilmesi anlamına gelirken, samimi davranış herhangi bir şekilde bilinçli veya stratejik olarak duyguların manüpüle edilmediği, kendiliğinden gerçekleşen veya doğal olarak hissedilen duygulardan oluşmaktadır (Anderson, 
2014: 21). Dahling ve Perez (2010: 575), bu durumun çalışanların örgütsel taleplere uygun olan duyguları doğal bir biçimde hissettiği zaman ortaya çıktığını belirtmektedir.

Dahling ve Perez (2010)'a göre samimi davranış, örgütün amaçları doğrultusunda çalışanlardan istenen davranışlardır. Örgütün istediği davranış kurallarıyla, çalışanın hissettiği duygular aynı doğrultuda olduğu zaman, çalışan yüzeysel ve derinlemesine davranış sergilemeyecek ve böylece duygusal emeğin olumsuz sonuçlarından daha az etkileneceklerdir. Diefendorff ve diğ. (2005)'e göre, çalışanların pozitif duygular ve pozitif ilişkiler arama çabalarının sonucu olarak duygularını doğal yollarla sergilemeleri sonucu çalışanların rol yapmalarına gerek kalmamaktadır. Ancak kendiliğinden gerçekleşen duygularıyla hareket eden çalışanlar istedikleri sonuçlara ulaşamadıkları zaman yüzeysel veya derinlemesine davranış sergileyeceklerdir (Savaş, 2012: 52).

\subsection{Hipotezlerin Olușturulması}

Yapılan araştırmalarda, bireylerin duygusal emek davranışlarını nasıl sergileyeceğinin bir belirleyicisi olarak bireysel farklılıkların rolü üzerinde durulmaktadırlar (Hochschild, 2003; Grandey, 2000; Keleş, 2014; Kızanlıkl1, 2014). Söz konusu bireysel farklılıklar bu araştırmada, literatürde en fazla araştırılan yaş ve cinsiyet değişkeni ile literatürde daha az araştırılan iş pozisyonu, sektör tecrübesi ve toplam çalışma süresi olarak incelenmiştir.

Hochschild (1983)'e göre yaş, duygusal emek davranışı üzerinde etkisi olan bir faktördür. Son zamanlarda yapılan birçok çalışma duygusal emek kullanımı ve yaş arasındaki ilişkiyi incelemiş ve yaşın duygusal emek davranışı sergilemede önemli bir özellik olduğunu belirtmişlerdir (Hochschild, 1983; Cheung ve Tang, 2010; Dahling ve Perez, 2010; Kruml ve Geddes, 2000; Cheung ve Wu, 2013; Lee, 2016; Cole, 2015). Yapilan çalışmalara bakıldığında ise duygusal deneyimlerin, iş tecrübelerinin ve kişisel motivasyonun yaşlandıkça arttı̆̆ 1 görülmektedir. Dahling ve Perez (2010), yaptıkları çalışmada iş yerinde duygusal emek kullanımında yaşlı çalışanların, olumsuz duygularını bastırarak olumlu duyguları arttırma yönündeki motivasyonlarını arttırdıkları sonucuna ulaşmışlardır. Dahling ve Perez (2010), yine aynı çalışmada, yaşın derinlemesine davranış ve samimi davranış sergileme ile pozitif ilişkili olduğunu, yüzeysel davranış sergilemeyle ise negatif ilişkili olduğu sonucuna ulaşmışlardır. Cheung ve Tang (2010) ise, yaptıkları çalışmada genç çalışanların yaşlı çalışanlara göre daha fazla duygusal uyumsuzluk yaşadıklarını belirtmişlerdir. Çünkü yaşlı çalışanlar zaman kavramını genç çalışanlara göre anlamlı bir şekilde kavradıklarından bugüne odaklanma motivasyonuna daha fazla sahiptirler ve iş yerinde duygularını düzenlemeye daha fazla zaman harcamaktadırlar (Cheung ve Tang, 2010: 325). Yaşlı çalışanlar daha önceki duygusal emek davranışı sergilemede elde ettikleri deneyim sayesinde (Kruml ve Geddes, 2000) genç çalışanlara göre duygularını daha iyi kontrol ederek uygun davranışı sergilemede daha başarılılardır. Aynı zamanda yaşlı çalışanların yaşlanmaya bağlı olarak iş ile ilgili daha az beklentiye sahip olmaları yaşlı çalışanlarda iş doyumunu arttırmaktadır (Cheung ve Tang, 2010: 326). Bu durum ise yaşlı çalışanların örgüte olan bağlılıklarını arttırmaktadır (Cole, 2015). Yaşlı çalışanların daha fazla yaşam tecrübesine sahip olmaları olumsuz duyguları bastırarak duyguların kontrolünde daha başarılı olmalarına neden olur ve bu sayede daha pozitif duygusal deneyimler üzerine odaklanırlar (Cheung ve Wu, 2013). Genç çalışanlar ise, duygularını kontrol etmede başarılı değillerdir ve daha az iş tecrübesine sahiptirler. Dolayısıyla, genç işçiler daha fazla duygusal tükenme ve işten ayrılma niyeti yaşayabilirler (Lee, 2016: 1341).

Teori ve görgül araştırmalardan yola çıkılarak yaş ve duygusal emek stratejileri arasındaki ilişkiye yönelik aşağıdaki hipotezler geliştirilmiş̧ir.

$\mathrm{H}_{1:}$ : Yüzeysel davranış yaşa göre anlamlı farklılık göstermektedir.

$\mathrm{H}_{2}$ : Derinden davranış yaşa göre anlamlı farklılık göstermektedir.

$\mathrm{H}_{3:}$ Samimi davranış yaşa göre anlamlı farklılık göstermektedir.

Cinsiyet farklılığının bireylerin rollerini belirleyen önemli bir faktör olmasından dolayı, kadın ve erkek davranışlarıyla ilgili toplumda birtakım beklentiler oluşmuştur. Bu beklentiler ise, kadın ve erkeklerde farklı duygu yönetimine neden olmuştur (Kızanlıklı, 2014: 28). Cinsiyet farklılı̆̆ının sadece toplumsal rollerde değil aynı zamanda iş yaşamında da önemli bir faktör olduğu görülmüş ve cinsiyet duygusal emek davranışları üzerinde etkisi olduğu düşünülen birçok çalışmada ele alınmıştır. (Erickson, 2005; Erickson ve Ritter, 2001; Hochschild, 1983; Hochschild 2000; Leidner, 1999; Meier ve di $\breve{g} ., 2006$; Cottingham ve diğ., 2015; Cheung ve Tang, 2010).

Hochschild (2003)'e göre, toplumun kadınları statü olarak ikinci plana itmesi kadınların diğer kaynaklardan yoksun kalmasına neden olmuştur ve bu durum kadınları daha fazla duygu yönetimine sevk etmiştir. Duygu yönetimi erkekler ve kadınlar için farklı şekillerde ortaya çıkmaktadır ve bireyler cinsiyetleri gereği duygusal emek gerektiren işlerde farklı roller üstlenebilmektedirler. Kadınlar doğaları gereği genellikle öfke ve kızgınlıkla başa çıkmayı gerektiren işlerde (örn, hosteslik) daha başarılıdırlar. Erkekler ise, doğaları gereği 
kuralları çiğneyenlere karşı daha sert tavırlar sergileyebilecekleri (örn, tahsildarlık) işlerde daha başarılıdırlar. Duygusal emek kullanımı kadın ve erkek arasında sadece mesleğe göre farklılaşmamaktadır. Bu farklılık aynı meslek kolunda da gerçekleşebilmektedir (Morris ve Feldman, 1996; Hochschild, 2003). Kadınların statü olarak ikinci plana itilmesi kadınları iş ortamında daha savunmasız bırakmıştır. Hochschild'in verdiği örnekte görüldüğü üzere erkek yolcular bayan hosteslere karşı saldırgan bir tavrı rahatlıkla sergileyebilmektedirler (Hochschild, 2003: 163). Kadınlar iş yerinde karşılaşmış oldukları bu olumsuz tavırlar karşısında daha fazla empati yapabilmekte ve erkeklere nazaran negatif duyguları bastırmada daha başarılı olarak değerlendirilmektedir (Walsh ve Bartikowski, 2013: 1219).

Hochschild (2003), yukarıda bahsedilen etkenler dolayı kadınların çalışma yaşamında erkeklerden daha fazla duygusal emek kullandıklarını ve kadınların doğası gereği başkalarının ihtiyaçlarına karşı hassas olmada, duygularını düzenlemede ve olumlu duygusal tepkiler ortaya koymakta erkeklere nazaran daha başarılı olduklarını ifade etmiştir.

Hochschild (1983, 2003), yaptığı çalışmalarda kadınların duygusal emek gerektiren işlerde daha başarılı olduğundan bahsetse de cinsiyete göre duygusal emek kullanımı toplum, örgüt, endüstri, statü, güç vb. koşullara göre değişebilmektedir. Çünkü bazı araştırmacılar (Cottingham vd., 2015; Cheung ve Tang, 2010; Grandey, 2000; Wharton ve Erickson, 1993), duygusal emek gösterimine kadınların daha çok başvurduğunu belirtse de Simon ve Nath (2004), yapmış olduğu çalışmada kadınların erkeklerden daha fazla duygusal sergilemedikleri sonucuna ulaşmışlardır. Erickson ve Ritter (2001) ve Erickson (2005) ise, duygusal emeğin etkilerinin cinsiyete göre değişmediğini bulmuştur.

Teori ve görgül araştırmalardan yola çıkılarak cinsiyet ve duygusal emek stratejileri arasındaki ilişkiye yönelik aşağıdaki hipotezler geliştirilmiştir.

$\mathrm{H}_{4}$ Yüzeysel davranış cinsiyete göre anlamlı farklılık göstermektedir.

$\mathrm{H}_{5}$ : Derinden davranış cinsiyete göre anlamlı farklılık göstermektedir.

$\mathrm{H}_{6:}$ Samimi davranış cinsiyete göre anlamlı farkl1lık göstermektedir.

Çalışanların görev yaptıkları iş pozisyonu duygusal emek stratejilerinde farklılığa neden olan bir diğer değişken olarak görülmektedir. Sezer Aydın (2017) yapmış olduğu çalışmada yönetici pozisyondaki çalışanların daha az duygusal emek kullandığını belirtmiştir. Kızanlıklı (2014)'e göre ise alt kademede görev yapan çalışanların üst kademede görev yapan çalışanlara nazaran daha fazla yüzeysel davranış sergiledikleri, üst kademede görev yapan çalışanların ise daha fazla derinden davranış ve samimi davranış sergilemeleri beklenmektedir. Kızanlıklı (2014) yapmış olduğu çalışmada üst kademedeki çalışanların alt kademede çalışanlara göre daha fazla samimi davranış sergilediği bulgusunu elde etmiştir.

Teori ve görgül araştırmalardan yola çıkılarak iş pozisyonu ve duygusal emek stratejileri arasındaki ilişkiye yönelik aşağıdaki hipotezler geliştirilmiştir.

$\mathrm{H}_{7}$ : Yüzeysel davranış çalışanların iş pozisyonlarına göre anlamlı farklılık göstermektedir.

$\mathrm{H}_{8:}$ Derinden davranış çalışanların iş pozisyonlarına göre anlamlı farklılık göstermektedir.

$\mathrm{H}_{9:}$ Samimi davranış çalışanların iş pozisyonlarına göre anlamlı farklılık göstermektedir.

Deneyim olarak ele alınan sektör tecrübesi ve çalışılan iş yerindeki toplam çalışma süresi ise duygusal emek stratejilerinde farklılığa neden olan diğer değişkenler olarak görülmektedir. Enki (2019)'a göre belirli bir iş deneyimine sahip çalışanlar örgütsel gösterim kurallarına uymada ve geliştirdikleri farklı çözüm yollarıyla sorunların çözümüne daha başarılı olabilmektedirler. Çalışanlar herhangi bir zorluk karşısında mesleki tecrübelerinden faydalanarak sorunların üstesinden gelebilmektedirler. Tekin (2018)'e göre ise özellikle de hizmet sektöründe deneyimi olan çalışanlar müşteriye karşı nasıl davranmaları gerektikleri hususunda tecrübe sahibi olduklarından müşterilerin olumsuz tavırlarını kendileri lehine çevirmede daha başarılıdırlar. Ayrıca Kızanlıklı (2014) ise daha az deneyime sahip çalışanların daha fazla duygusal çaba harcadıklarını belirtmiştir. Kızanlıklı (2014) yapmış olduğu çalışmada sektör tecrübesi ve çalışılan iş yerindeki toplam çalışma süresi daha fazla olan çalışanların sektör tecrübesi ve çalışılan iş yerindeki toplam çalışma süresi daha az olan çalışanlara göre daha fazla samimi davranış sergiledikleri bulgusunu elde etmiştir. Keleş (2014) ise yapmış olduğu çalışmada sektör tecrübesi ve çalışılan iş yerindeki toplam çalışma süresi daha fazla olan çalışanların daha az olan çalışanlara göre daha fazla yüzeysel ve derinden davranış sergiledikleri bulgusunu elde etmiştir.

Teori ve görgül araştırmalardan yola çıkılarak sektör tecrübesi ve çalışılan iş yerindeki toplam çalışması süresi ile duygusal emek stratejileri arasındaki ilişkiye yönelik aşağıdaki hipotezler geliştirilmiştir.

$\mathrm{H}_{10}$ : Yüzeysel davranış sektör tecrübesine göre anlamlı farkl1l1k göstermektedir.

$\mathrm{H}_{11}$ : Derinden davranış sektör tecrübesine göre anlamlı farklılık göstermektedir.

$\mathrm{H}_{12}$ : Samimi davranış sektör tecrübesine göre anlamlı farklılık göstermektedir. 
$\mathrm{H}_{13}$ Yüzeysel davranış toplam çalışma süresine göre anlamlı farklılık göstermektedir.

$\mathrm{H}_{14}$ : Derinden davranış toplam çalışma süresine göre anlamlı farklılık göstermektedir.

$\mathrm{H}_{15}$ : Samimi davranış toplam çalışma süresine göre anlamlı farklılık göstermektedir.

\section{ARAŞTIRMANIN YÖNTEMI}

Bu çalışmada öncelikli olarak araştırma ölçeğinin yapı geçerliği ve güvenilirliği test edilmiştir. Bu amaçla keşfedici ve doğrulayıcı faktör analizleri ile güvenilirlik analizi yapılmıştır. Ardından katılımcıların bazı demografik özellikleri ile ilgili bilgiler verilmiştir. SPSS ve AMOS paket programları ile yapılan analiz sonuçlarına değinilmiş ve bulunan sonuçlara ilişkin yorum yapılmıştır.

\subsection{Araştırmanın Örneklemi ve Bazı Demografik Özellikleri}

Araştırmanın örneklemini Gaziantep, Adana ve Osmaniye illerindeki dört ve beş yıldızlı otel çalışanlarından 549 kişi oluşturmaktadır. Araştırmaya katılan katılımcıların 207'si 18-30 yaş aralığında, 222'si 31-40 yaş aralığında, 120'si 41 ve üzeri yaşa sahiptir. Katılımcıların 117'si kadın 432'si ise erkeklerden oluşmaktadır. Katılımcıların, 43'ü ilköğretim, 430'u lise, 53'ü ön lisans, 23'ü ise lisans mezunudur. Katılımcıların 72'si yönetici pozisyonunda 477'si ise işçilerden oluşmaktadır. Katılımcıların 137'si 1 yıldan daha az, 272'si 1-3 yıl arası, 140'1 4 yıl ve üzeri süreli aynı iş yerinde çalışmaktadırlar. Katılımcıların 51'i sektörde bir yıldan az, 137'si 1-3 yıl arası, 111'i 4-6 yıl arası, 143'ü 7-9 yıl arası, 107'si ise 10 yıl ve üstü sektör tecrübesine sahiptir.

\subsection{Veri Toplama Yöntem ve Araçları}

Anket soruları 5'li likert ölçeğine göre hazırlanmıştır. Katılımcıların duygusal emek algılarının ölçülmesinde Diefendorff ve diğg. (2005) tarafından geliştirilen ve Türkçe uyarlaması Basım ve Beğenirbaş (2012) tarafından yapılan ölçek kullanılmıştır. Ölçek; yüzeysel davranış sergileme (6 ifade), derinlemesine davranış sergileme (4 ifade) ve samimi davranışlar (3 ifade) olmak üzere üç ayrı boyuttan ve toplam 13 ifadeden oluşmaktadır. Katılımcılar, ölçekte yer alan; "Müşterilerle uygun şekilde ilgilenebilmek için rol yaparım", "Müşterilerime, gerçek hissettiğim duygulardan farklı duygular sergilerim", "Müşterilere gösterdiğim duygular kendiliğinden ortaya çıkar" şeklindeki ifadelere ne oranda katıldıklarını beşli likert ölçeği ile belirlemişlerdir (1=Hiçbir Zaman, 5= Her Zaman). Diefendorff vd. (2005) araştırmasında ölçeğin güvenirlik katsayısını yüzeysel davranış boyutu için $\alpha=0,92$, derinlemesine davranış boyutu için $\alpha=0,85$ ve samimi davranış boyutu için ise $\alpha=0,83$ olarak bildirmiştir. Basım ve Beğenirbaş (2012) ise, araştırmasında ölçeğin güvenirlik katsayısını birinci örneklemde; yüzeysel davranış boyutu için $\alpha=0,83$, derinlemesine davranış boyutu için $\alpha=0,87$ ve samimi davranış boyutu için $\alpha=0,80$ ve ikinci örneklemde ise yüzeysel davranış boyutu için $\alpha=0,84$, derinlemesine davranış boyutu için $\alpha=0,86$ ve samimi davranış boyutu için $\alpha$ $=0,86$ olarak bildirmiștir.

Çalışmada ilk olarak ölçeklerin yapı geçerliği ve güvenilirliği çalışması yapılmıştır. Bu amaçla öncelikle ölçeklerin keşfedici ve doğrulayıcı faktör analizleri yapılmış ardından da güvenilirlik analizleri yapılmıştır. Duygusal emek ölçeğinin keşfedici faktör analizi sonuçları Tablo 1'de, doğrulayıcı faktör analizi sonucu elde edilen uyum iyiliği değerleri ise Tablo 2'de sunulmuştur. Tanımlayıcı istatistik, korelasyon ve güvenirlilik analizi sonuçları ise Tablo 3'te verilmiştir. 
Tablo 1. Duygusal Emek Ölçeği Keşfedici Faktör Analizi

\begin{tabular}{|l|c|c|c|}
\hline \multirow{2}{*}{} & \multicolumn{2}{|c|}{ Faktör Yükleri } \\
\cline { 2 - 4 } & $\begin{array}{c}\text { Yüzeysel } \\
\text { Davran1ş }\end{array}$ & Derinlemesine Davranış & Samimi Davranış \\
\hline S1 & 0,823 & & \\
\hline S2 & 0,844 & & \\
\hline S3 & 0,846 & & \\
\hline S4 & 0,840 & & \\
\hline S5 & 0,826 & & \\
\hline S6 & 0,811 & & \\
\hline S7 & & 0,807 & \\
\hline S8 & & 0,884 & 0,895 \\
\hline S9 & & 0,902 & 0,936 \\
\hline S10 & & 0,855 & 0,883 \\
\hline S11 & & & \\
\hline S12 & & & \\
\hline S13 & & & \\
\hline
\end{tabular}

Tablo 1'de yapılan keşfedici faktör analizi neticesinde duygusal emeğin üç faktör altında toplandığ 1 görülmüştür. KMO (Kaiser-Meyer-Olkin) testi sonunda KMO değeri 0,748 olarak tespit edilmiş olup faktör analizi için örneklem büyüklüğ̈̈ yeterlidir. Bartlett's Küresellik Testi sonucunda Ki Kare değeri 5816.009, serbestlik derecesi değeri (df) 78 ve Sig. Değeri ,000 bulunmuş olup veriler çok değişkenli normal dağılımdan gelmektedir ve faktör analizine uygundur. Keşfedici faktör analizi neticesinde ölçeğin 1,2,3,4,5,6 numaralı maddelerinin yüzeysel davranışı; 7,8,9,10 numaralı maddelerinin derinlemesine davranışı; 11,12,13 numaralı maddelerin ise samimi davranışı temsil ettiği görülmüştür. Faktör yüklerinin ise, 0,807 ile 0,936 arasında olduğu söylenebilir. Yapılan KFA sonucunda üç faktörlü yapıya sahip olan ölçeğin toplam varyansın \% 75,742'sini açıkladığı tespit edilmiştir.

Ölçeğin elde edilen üç boyutlu yapısını doğrulamak için AMOS paket programı yardımı ile doğrulayıcı faktör analizi yapılmıştır. Duygusal emek ölçeğinin doğrulayıcı faktör analizi Şekil 1'de ve uyum iyiliği değerleri ise Tablo 2' de verilmiştir.

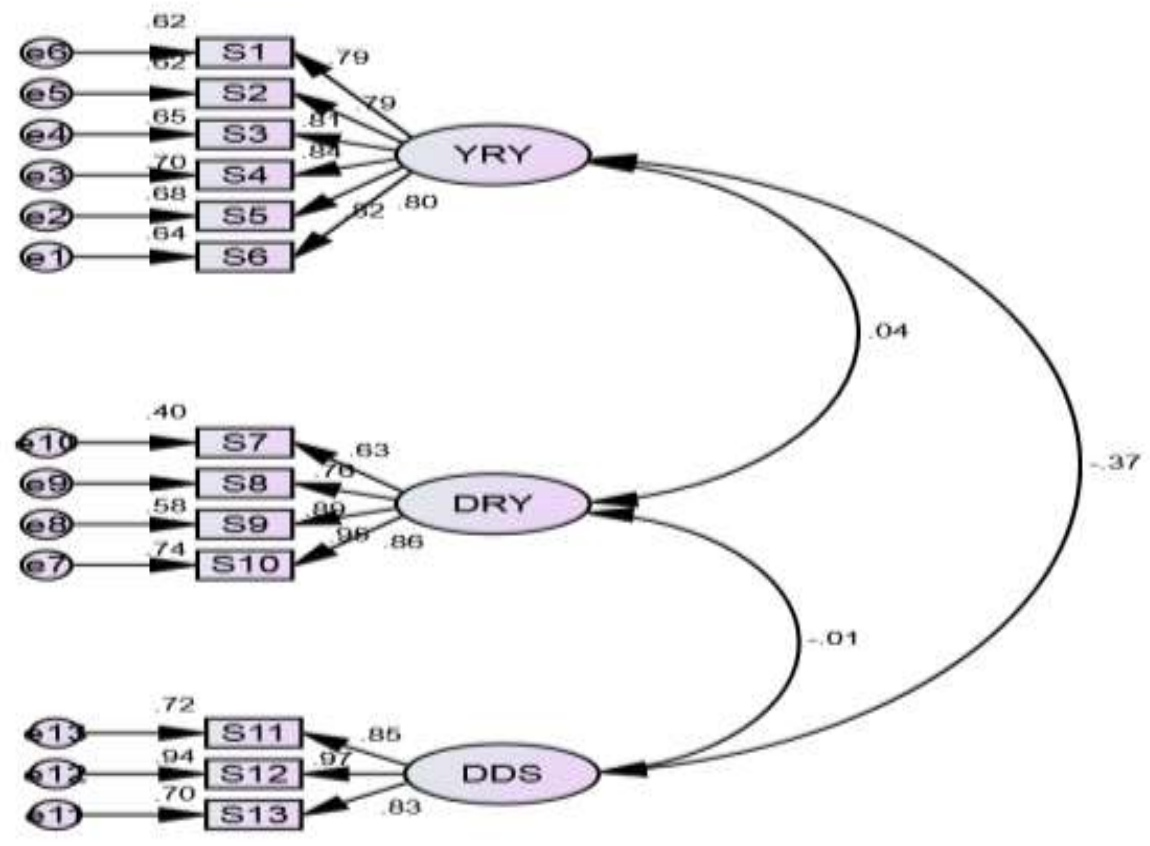

Şekil 1. Duygusal Emek Ölçeği DFA 
DFA sonucu, yüzeysel davranış boyutunun faktör yükleri 0,79 ile 0,84 ; derinlemesine davranış boyutunun faktör yüklerinin 0,63 ile 0,96 ve samimi davranış sergileme boyutunun faktör yüklerinin ise 0,83 ile 0,97 aralığında değer aldığı görülmüş̧tür. Ayrıca yüzeysel davranış ile samimi davranış sergileme arasında ters yönlü düşük düzeyde, derinlemesine davranış ile samimi davranış sergileme arasında ters yönde düşük düzeyde, yüzeysel davranış ile derinlemesine davranış arasında aynı yönde düşük düzeyde korelasyon tespit edilmiştir.

Tablo 2. Duygusal Emek Uyum İyiliği Değerleri

\begin{tabular}{|c|c|c|c|c|c|c|c|c|}
\hline Değişken & $\mathrm{X}^{2}$ & $\mathrm{df}$ & $\begin{array}{c}\text { CMIN/ } \\
\text { DF }\end{array}$ & GFI & AGFI & CFI & TLI & RMSEA \\
\hline $\begin{array}{c}\text { Duygusal } \\
\text { Emek }\end{array}$ & 181.554 & 50 & 3.631 & .956 & .92 & .978 & 965 & 0.069 \\
\hline
\end{tabular}

Faktör analizlerinden sonra ölçeğin tanımlayıcı istatistik, korelasyon ve güvenirlilik analizleri yapılmış analiz sonuçları Tablo 3'te verilmiştir.

Tablo 3.Tanımlayıcı İstatistik, Korelasyon ve Güvenirlilik Analizi

\begin{tabular}{|l|c|c|c|c|c|c|}
\hline Değişken & $\begin{array}{c}\text { Cronbach } \\
\text { Alpha } \\
\text { Katsayıs1 }\end{array}$ & Ortalama & $\begin{array}{c}\text { Sdt } \\
\text {.Sapma }\end{array}$ & $\begin{array}{c}\text { Yüzeysel } \\
\text { Davranış }\end{array}$ & $\begin{array}{c}\text { Derinlemesine } \\
\text { Davranış }\end{array}$ & $\begin{array}{c}\text { Samimi } \\
\text { Davranı̧̧ }\end{array}$ \\
\hline $\begin{array}{l}\text { Yüzeysel } \\
\text { Davranış }\end{array}$ & .919 & 2.8880 & 1.18175 & 1 & 1 & \\
\hline $\begin{array}{l}\text { Derinlemesine } \\
\text { Davranış }\end{array}$ & .885 & 3.7386 & 1.00420 & .061 & & 1 \\
\hline $\begin{array}{l}\text { Samimi } \\
\text { Davranış }\end{array}$ & .913 & 3.1032 & 1.03853 &,$- 352^{* *}$ & .005 & \\
\hline
\end{tabular}

*** 0,01 anlamlılık düzeyinde anlamlı

Tablo 3 ’te görüldüğü gibi korelasyon analizi sonucunda, samimi davranış sergileme ile yüzeysel davranış sergileme arasında $(\mathrm{r}=-, 352)$ orta düzeyde negatif yönde anlamlı bir ilişki bulunmuştur. Güvenilirlik analizi sonucu Cronbach's Alpha katsayısı yüzeysel davranış için 0,919; derinlemesine davranış için 0,885; samimi davranış için 0,913 olarak bulunmuştur. Bu sonuçlar bütün değişkenlerin güvenilir olduğunu göstermektedir $(0,80 \leq \alpha<1,00)$. Verilerin normal dağılıma sahip olup olmadığını test etmek amacıyla değişkenlerin basıklık ve çarpıklık değerlerine bakılmıştır. Basıklık ve çarpıklık değerleri -2 ile +2 arasında tespit edildiğinden veriler normal dağılıma sahiptir (Bayram, 2013:109).

\subsection{Bulgular}

\subsubsection{Yaş Değişkeni Varyans Analizi}

Değişkenlerin katılımcıların yaşlarına göre anlamlı farklılık gösterip göstermediğini test etmek için varyans analizi yapılmış ve analiz sonuçları Tablo 4'te verilmiştir. 
Tablo 4. Yaş Değişkeni Varyans Analizi Sonuçları

\begin{tabular}{|c|c|c|c|c|c|c|}
\hline & & $\begin{array}{l}\text { Kareler } \\
\text { Toplamı }\end{array}$ & Std.Hata & $\begin{array}{c}\text { Kareler } \\
\text { Ortalaması }\end{array}$ & $\mathrm{F}$ & Anlamlıl1k \\
\hline \multirow[t]{3}{*}{$\begin{array}{l}\text { Yüzeysel } \\
\text { Davranış }\end{array}$} & Gruplar aras1 & 30.461 & 2 & 15.230 & 11.316 & . 000 \\
\hline & Gruplar içi & 734.844 & 546 & 1.346 & & \\
\hline & Toplam & 765.305 & 548 & & & \\
\hline \multirow[t]{3}{*}{$\begin{array}{c}\text { Derinlemesine } \\
\text { Davranış }\end{array}$} & Gruplar aras1 & 1.278 & 2 & .639 & .633 & .532 \\
\hline & Gruplar içi & 551.339 & 546 & 1.010 & & \\
\hline & Toplam & 552.616 & 548 & & & \\
\hline \multirow[t]{3}{*}{$\begin{array}{c}\text { Samimi } \\
\text { Davranış }\end{array}$} & Gruplar aras1 & 18.771 & 2 & 9.385 & 8.955 & .000 \\
\hline & Gruplar içi & 572.269 & 546 & 1.048 & & \\
\hline & Toplam & 591.040 & 548 & & & \\
\hline
\end{tabular}

Varyans analizi sonuçlarına göre yüzeysel davranış ve samimi davranış yaşa göre anlamlı farklılık göstermektedir. Farklılığın yönünü görebilmek için Tukey testi yapılmıştır. Tukey testi sonuçlarına göre, yüzeysel davranış sergileme 18-30, 31-40 ve 41-50 arası yaşa sahip olanlar arasında 18-30 yaş grubu lehine anlamlı farklılık göstermektedir. Yani, 18-30 yaş aralığında olan çalışanlar, 31-40 ile 41-50 arası yaş aralığında olan çalışanlara göre daha yüksek düzeyde yüzeysel davranış sergilemektedir. Samimi davranış sergileme ise 18-30, 31-40 ve 41-50 arası yaşa sahip olanlar arasında 31-40 yaş grubu lehine anlamlı farklılık göstermektedir. Yani 31-40 yaş aralığında olan çalışanlar, 18-30 ile 41-50 arası yaş aralığında olan çalışanlara göre daha yüksek düzeyde samimi davranış sergilemektedirler. Bu sonuçlara göre, H1 ve H3 hipotezleri kabul edilmiştir.

\subsubsection{Cinsiyet Değișkeni Bağımsız Örneklem Testi}

Değişkenlerin katılımcıların cinsiyetlerine göre anlamlı farklılık gösterip göstermediğini test etmek için bağımsız örneklem testi yapılmış ve analiz sonuçları Tablo 5'te verilmiştir. 
Tablo 5. Cinsiyet Bağımsız Örneklem Testi

\begin{tabular}{|c|c|c|c|c|}
\hline & & & & \\
& $\mathrm{F}$ & $\mathrm{t}$ & $\mathrm{sd}$ & Sig. (2-tailed) \\
\hline Yüzeysel Davranış & .342 & 4.018 & 547 & .000 \\
\cline { 2 - 5 } & & 4.004 & 182.894 & .000 \\
\hline Derinden Davranış & 4.605 & -.069 & 547 & .945 \\
\cline { 2 - 5 } & & -.065 & 168.387 & .949 \\
\hline Samimi Davranış & .283 & -5.356 & 547 & .000 \\
\cline { 2 - 5 } & & -5.421 & 186.761 & .000 \\
\hline
\end{tabular}

Bağımsız örneklem testi sonucunda yüzeysel davranış sergileme kadınlar ile erkekler arasında kadınlar lehine anlamlı farklılık göstermektedir. Yani, kadınlar erkeklere göre daha yüksek düzeyde yüzeysel davranış sergilemektedirler. Samimi davranış sergileme ise kadınlar ile erkekler arasında erkekler lehine anlamlı farklı1ık göstermektedir. Yani, erkekler kadınlardan daha yüksek düzeyde samimi davranış sergilemektedirler. Bu sonuçlara göre, H4 ve H6 hipotezleri kabul edilmiştir.

\subsection{3. Çalışanların Pozisyonu Değişkeni Bağımsız Örneklem Testi}

Değişkenlerin yöneticiler ve işçiler arasında anlamlı farkl1lık gösterip göstermediğini test etmek için bağımsız örneklem testi yapılmış ve analiz sonuçları Tablo 6'da verilmiştir.

Tablo 6. Pozisyon (Yönetici ve İşçi) Bağımsız Örneklem Testi

\begin{tabular}{|c|c|c|c|c|}
\hline \multirow{2}{*}{} & & & & \\
& & & & \\
& $\mathrm{F}$ & $\mathrm{t}$ & $\mathrm{sd}$ & Sig. (2-tailed) \\
\hline \multirow{2}{*}{ Yüzeysel Davranış } & .255 & -1.977 & 547 & .048 \\
\cline { 2 - 5 } & & -2.009 & 94.788 & .047 \\
\hline Derinden Davranış & .009 & -.998 & 547 & .318 \\
\cline { 2 - 5 } & & -1.001 & 93.868 & .320 \\
\hline Samimi Davranış & 1.198 & 1.982 & 547 & .048 \\
\cline { 2 - 5 } & & 2.100 & 97.847 & .038 \\
\hline
\end{tabular}

Bağımsız örneklem testi sonucunda samimi davranış sergileme işçiler ile yöneticiler arasında yöneticiler lehine iş pozisyonuna göre anlamlı farklılık göstermektedir. Yani, yöneticiler işçilerden daha yüksek düzeyde samimi davranış sergilemektedirler. Bu sonuçlara göre $\mathrm{H} 9$ hipotezi kabul edilmiştir.

\subsubsection{Sektör Tecrübesi Varyans Analizi}

Değişkenlerin sektör tecrübesine göre anlamlı farklılık gösterip göstermediğini analiz etmek için varyans analizi yapılmış ve analiz sonuçları Tablo 7'de verilmiştir. 
Tablo 7. Sektör Tecrübesi Varyans Analizi

\begin{tabular}{|c|c|c|c|c|c|c|}
\hline & & $\begin{array}{c}\text { Kareler } \\
\text { Toplam }\end{array}$ & Std.Hata & $\begin{array}{c}\text { Kareler } \\
\text { Ortalamas1 }\end{array}$ & $\mathrm{F}$ & Anlamlilık \\
\hline \multirow{3}{*}{$\begin{array}{l}\text { Yüzeysel } \\
\text { Davranış }\end{array}$} & $\begin{array}{c}\text { Gruplar } \\
\text { aras1 }\end{array}$ & 30.771 & 4 & 7.693 & 5.697 & .000 \\
\hline & Gruplar içi & 734.534 & 544 & 1.350 & & \\
\hline & Toplam & 765.305 & 548 & & & \\
\hline \multirow{3}{*}{$\begin{array}{l}\text { Derinlemesi } \\
\text { ne Davranış }\end{array}$} & $\begin{array}{c}\text { Gruplar } \\
\text { aras1 }\end{array}$ & 2.812 & 4 & .703 & .695 & .595 \\
\hline & Gruplar içi & 549.805 & 544 & 1.011 & & \\
\hline & Toplam & 552.616 & 548 & & & \\
\hline \multirow{3}{*}{$\begin{array}{l}\text { Samimi } \\
\text { Davranış }\end{array}$} & $\begin{array}{l}\text { Gruplar } \\
\text { aras1 }\end{array}$ & 30.083 & 4 & 7.521 & 7.293 & .000 \\
\hline & Gruplar içi & 560.957 & 544 & 1.031 & & \\
\hline & Toplam & 591.040 & 548 & & & \\
\hline
\end{tabular}

Varyans analizi sonuçlarına göre yüzeysel davranış ve samimi davranış, sektör tecrübesine göre anlamlı farklılık gösterdiği görülmüştür. Farklılığın yönünü test edebilmek için Tukey testi yapılmıştır. Tukey testi sonuçlarına göre; Yüzeysel davranış sergileme 1 yıldan az, 1-3 yıl, 4-6 yıl ve 7-9 yıl arası ile sahip olanlar ile 10 y1l ve üzeri tecrübeye sahip olanlar arasında 1-3 yıl arası tecrübeye sahip olanlar lehine anlamlı farkl1lı göstermektedir. Yani, 1-3 yıl arası tecrübeye sahip olan çalışanlar 1 yıldan az, 4-6 yıl ve 7-9 yıl arası tecrübeye sahip olanlar ile 10 yıl ve üzeri tecrübeye sahip olan çalışanlara göre daha yüksek düzeyde yüzeysel davranış sergilemektedirler. Samimi davranış sergileme ise 1 yıldan az, 1-3 yı1, 4-6 yıl ve 7-9 yıl arası ile sahip olanlar ile 10 yıl ve üzeri tecrübeye sahip olanlar arasında 10 yıl ve üzeri tecrübeliler lehine anlamlı farklılık göstermektedir. Yani, 10 yıl ve üzerinde bir tecrübeye sahip olan çalışanlar 1 yıldan az, 1-3 yıl, 4-6 yıl ve 7-9 yıl arası tecrübeye sahip olan çalışanlardan daha yüksek düzeyde samimi davranış sergilemektedirler.

$\mathrm{Bu}$ sonuçlara göre, $\mathrm{H} 10$ ve $\mathrm{H} 12$ hipotezleri kabul edilmiştir.

\subsubsection{Toplam Çalışma Süresi Varyans Analizi Testi}

Değişkenlerin katılımcıların hali hazırdaki otelde toplam çalıma sürelerine göre anlamlı farklılık gösterip göstermediğini analiz etmek için varyans analizi yapılmış ve analiz sonuçları Tablo 9'da verilmiştir. 
Tablo 9. Toplam Çalışma Süresi Varyans Analizi Testi Sonuçları

\begin{tabular}{|c|c|c|c|c|c|c|}
\hline \multicolumn{2}{|c|}{} & $\begin{array}{c}\text { Kareler } \\
\text { Toplamı }\end{array}$ & Std.Hata & $\begin{array}{c}\text { Kareler } \\
\text { Ortalaması }\end{array}$ & F & Anlamlılık \\
\hline $\begin{array}{c}\text { Yüzeysel } \\
\text { Davranış }\end{array}$ & $\begin{array}{c}\text { Gruplar } \\
\text { aras1 }\end{array}$ & 27.948 & 2 & 13.974 & 10.347 & .000 \\
\cline { 2 - 7 } & $\begin{array}{c}\text { Gruplar } \\
\text { içi }\end{array}$ & 737.358 & 546 & 1.350 & & \\
\cline { 2 - 8 } & Toplam & 765.305 & 548 & & & \\
\hline $\begin{array}{c}\text { Derinlemesine } \\
\text { Davranış }\end{array}$ & $\begin{array}{c}\text { Gruplar } \\
\text { aras1 }\end{array}$ & 4.381 & 2 & 2.191 & 2.182 & .114 \\
\cline { 2 - 8 } & $\begin{array}{c}\text { Gruplar } \\
\text { içi }\end{array}$ & 548.235 & 546 & 1.004 & & \\
\cline { 2 - 8 } & Toplam & 552.616 & 548 & & 29.818 & .000 \\
\hline \multirow{2}{*}{$\begin{array}{c}\text { Samimi } \\
\text { Davranış }\end{array}$} & $\begin{array}{c}\text { Gruplar } \\
\text { aras1 }\end{array}$ & 58.198 & 2 & 29.099 & & \\
\cline { 2 - 8 } & $\begin{array}{c}\text { Gruplar } \\
\text { içi }\end{array}$ & 532.842 & 546 & .976 & & \\
\cline { 2 - 8 } & Toplam & 591.040 & 548 & & & \\
\hline
\end{tabular}

Varyans analizi sonuçlarına göre yüzeysel davranış ve samimi davranış toplam çalı̧̧ma süresine göre anlamlı farklılık göstermektedir. Farklılığın yönünü görebilmek için Tukey testi yapılmıştır. Tukey testi sonuçlarına göre; yüzeysel davranış sergileme, 1 yıldın az çalışanlar ve 1-3 yıl arası çalışanlar ile 4 yıl ve üzeri çalışanlar arasında 1 yıldan az süre çalışanlar lehine anlamlı farklılık göstermektedir. Yani, 1 yıldın az çalışanlar 1-3 yıl arası çalışanlar ile 4 yıl ve üzeri çalışanlara göre daha yüksek düzeyde yüzeysel davranış sergilemektedirler. Samimi davranış sergileme, 1 yıldın az çalışanlar ve 1-3 yıl arası çalışanlar ile 4 yıl ve üzeri çalışanlar arasında 4 yıl ve üzeri çalışanlar lehine anlamlı farklılık göstermektedir. Yani, 4 yıl ve üzeri çalışanlar 1 yıldan az çalışanlar ile 1-3 yıl arası çalışanlara göre daha yüksek düzeyde samimi davranış sergilemektedirler. Bu sonuçlara göre, H13 ve H15 hipotezleri kabul edilmiştir.

\section{SONUÇ}

Çalışanların davranışları üzerinde etkili olan birçok faktör bulunmaktadır. 1979 yılında ilk olarak çalışılmaya başlandığından bugüne kadar duygusal emeğinde etkilendiği birçok öncülün varlığından bahsedilmiştir. Genel olarak kavramın öncülerinin yapmış oldukları çalışmalar ve daha sonrasında da yapılan çalışmalar doğrultusunda, duygusal emeği etkileyen bireysel faktörlerin yaş, cinsiyet, işletmedeki pozisyon, çalışılan iş yerindeki toplam çalışma süresi ve sektör tecrübesi olarak gruplandığı görülmektedir (Hochschild, 2003; Grandey, 2000; Cheung ve Tang, 2010; Keleş, 2014; Kızanlıklı, 2014).

Bireylerin toplumda üstlenmiş oldukları rollerin örgütlere yansımasıyla birlikte, örgütlerde çalışanların sahip oldukları bireysel farklılıklarının, organizasyon içerisinde çalışanların üstlendiği görevlere göre şekillendiği görülmektedir. Bu çalışmanın amacı demografik değişkenlerin çalışanların duygusal emek kullanım düzeylerine olan etkisi belirlenmeye çalışmaktır. $\mathrm{Bu}$ amaçla yapılan analizler neticesinde, çalışanların duygusal emek davranışları düzeylerine ilişkin görüşleri; cinsiyetlerine, yaşlarına, işletmedeki pozisyonlarına, sektördeki toplam çalışma sürelerine ve iş yerindeki toplam çalışma sürelerine göre anlamlı farkl1l1klar göstermektedir.

Hochschild (1983)'e göre yaş, duygusal emek davranışı üzerinde etkisi olan önemli bir faktördür. Bu araştırmada da, duygusal emek sergileme stratejilerinden yüzeysel davranış sergileme ve samimi davranış sergileme ile katılımcıların yaşları arasında anlamlı bir ilişki olduğu tespit edilmiş, derinlemesine davranış ile herhangi bir ilişki tespit edilememiştir. Buna göre; araştırmaya katılanların yaşlarının artmasıyla birlikte samimi davranış sergileme eğilimlerinin de arttığı bununla birlikte yüzeysel davranış sergileme düzeylerinin ise azaldığ sonucuna varmak mümkündür. Araştırmada elde edilen bu bulgu, Hochschild (1983), Cheung ve Tang (2010), Dahling ve Perez (2010), Kruml ve Geddes (2000), Cheung ve Wu (2013), Lee (2016) ve Cole (2015)'un çalışmalarının sonuçları ile tutarlılık göstermektedir. Yaşın ilerlemesi ile birlikte çalışanların duygusal emek davranışı sergilemede elde ettikleri deneyim göz önüne alındığında, yaşlı çalışanların genç çalışanlara göre duygularını kontrol etmede duygusal uyumsuzluk yaşamadıkları ve gösterim kurallarına uygun hareket ederek yüzeysel davranış sergilemekten çok samimi davranış sergilemede daha başarılı 
olduklarını söylemek mümkündür. Ayrıca otelcilik sektörü açısından çalışanların yaşlarının artması deneyimin bir göstergesi olduğu gibi aynı zamanda da yaşın artmasının müşteri etkileşiminde yüzeysel davranıştan ziyade samimi davranış sergilenmesi üzerinde etkili olduğu değerlendirilmesi yapılabilmektedir.

Kadın ve erkeklerin duygusal emek kullanımlarının farklı olabileceğini belirten Hochschild (1983, 2003)'e göre cinsiyet, duygusal emek kullanımında önemli bir etkendir. Hochschild $(1983,2003)$ yaptığı çalışmalarda kadınların duygusal emek gerektiren işlerde daha başarılı olduğundan bahsetmiştir. Yaş değişkeninde olduğu gibi duygusal emek sergileme stratejilerinden yüzeysel davranış sergileme ve samimi davranış sergileme ile katılımcıların cinsiyetleri arasında anlamlı bir ilişki olduğu tespit edilmiş, derinlemesine davranış ile herhangi bir ilişki tespit edilememiştir. Araştırmada kadınların, erkeklerden daha fazla yüzeysel davranış sergilediği ve erkeklerin kadınlara göre daha fazla samimi davranış sergilediği bulgusu edilmiştir. Bu bulgu; turizm sektöründeki zor çalışma koşullarına erkek çalışanların kadın çalışanlara göre daha iyi uyum sağlayabildikleri ve duygusal uyumsuzluk yaşamadan hissetmiş oldukları samimi duyguları sergilemede kadın çalışanlardan daha başarılı oldukları ile açıklanabilir. Bu bulgu Biron ve Veldhowen (2012) ve Schaubroeck ve Jones (2000) çalışma bulgularıyla uyumludur. Konu ile ilgili önceki araştırmalara bakıldığında bazı araştırmacılar, örneğin; Cottingham ve diğ. (2015), Cheung ve Tang (2010), Grandey (2000) ve Wharton ve Erickson (1993) duygusal emek gösterimine kadınların daha çok başvurduğunu belirtmiş olsalar da Simon ve Nath (2004) yapmış oldukları çalışmada kadınların erkeklerden daha fazla duygusal emek sergilemedikleri sonucuna ulaşmışlardır. Erickson ve Ritter (2001) ve Erickson (2005) ise duygusal emeğin etkilerinin cinsiyete göre değişmediğini tespit etmişlerdir. Yapılan bu çalışmalarda görüleceği üzere duygusal emek gösteriminin cinsiyete göre farklılaşıp farklılaşmadığı hususunda ortak bir değerlendirme yapılamamaktadır. Duygusal emek gösteriminin kadın ve erkekler arasında toplum, örgüt, endüstri, statü, güç vb. koşullara göre değiş̧ebileceği söylenebilir. $\mathrm{Bu}$ araştırmada ortaya çıkan sonuçlar yalnızca örneklem grubunun ve kadın-erkek sayısından ve özelliklerinden yola çıkılarak değerlendirilebileceği için aynı alanda yapılan başka bir araştırmada ortaya çıkabilecek farklı sonuçlar normal karşılanmalıdır.

Çalışanların işletmedeki pozisyonlarının duygusal emek kullanımında bir farklılığa sebep olup olmadığına yönelik bulgular incelendiğinde, çalışanların pozisyonları ile duygusal emek stratejilerinden samimi davranış arasında anlamlı ilişki tespit edilmiş, yüzeysel davranış sergileme ve derinlemesine davranış sergileme ile ilişki tespit edilememiştir. Araştırmada yöneticilerin işçilerden daha fazla samimi davranış sergiledikleri bulgusu elde edilmiştir. Bu bulgu Sezer Aydın (2017) ve Kızanlıklı (2014) çalışma bulgularıyla uyumludur. Araştırmadan elde edilen bu bulguya göre yöneticilerin yıllar içinde elde ettikleri deneyim sayesinde işçilere nazaran derinlemesine davranış ve yüzeysel davranış sergileme ihtiyacı duymadıkları ve kendi hissetmiş oldukları duygularını iş süreçlerine yansıttıkları değerlendirilmesini yapmak mümkündür.

Çalışanların, hali hazırda çalıştıkları oteldeki toplam çalışma sürelerinin duygusal emek kullanımında bir farklılığa sebep olup olmadığına yönelik bulgular incelendiğinde, çalışanların yüzeysel veya samimi davranış sergilemeleri ile oteldeki toplam çalışma süreleri arasında anlamlı farklılık tespit edilmiş, derinlemesine davranış ile bir ilişki tespit edilememiştir. Araştırmada otelde bir yıldan daha az çalışanların yüzeysel davranış sergiledikleri, dört yıl ve üzeri çalışanların ise samimi davranış sergiledikleri görülmüştür. Araştırmada elde edilen bu bulgu Kızanlıklı (2014) çalışmasında elde edilen bulguyla örtüşmektedir. Bu bulgu, otelde uzun süre çalışan personelin duygusal deneyim ve iş tecrübelerinin artmasıyla birlikte müşteri etkileşiminde duygusal emek kullanımında duygusal uyumsuzluk yaşamadan ve yüzeysel davranış ile derinlemesine davranış sergileme ihtiyacı hissetmeden hissetmiş oldukları duyguları müşterilere samimi davranış sergileyerek gösterdikleri değerlendirmesi ile açıklanmaktadır.

Araştırmadaki bir diğer değişken olan çalışanların otelcilik sektöründeki toplam sektör tecrübelerinin duygusal emek kullanımında bir farklılığa sebep olup olmadığına yönelik bulgular incelendiğinde, çalışanların toplam sektör tecrübeleri ile duygusal emek stratejilerinden yüzeysel veya samimi davranış sergilemeleri arasında anlamlı farklılık tespit edilmiş, derinlemesine davranış ile bir ilişki tespit edilememiştir. Otelcilik sektöründe 1-3 yıl arası deneyime sahip olan çalışanların yüzeysel davranış sergiledikleri, 10 yıl ve üzerinde deneyime sahip olan çalışanların ise samimi davranış sergiledikleri görülmüştür. Bu bulgular önceki bazı araştırma bulgularıyla da örtüşmektedir. Örneğin; Cheung ve Tang (2010), Kruml ve Geddes (2000) ve Kızanlıklı (2014). Gerek hali hazırdaki otelde toplam çalışma süresi, gerekse de otelcilik sektöründeki toplam deneyimin duygusal emek kullanımına olan etkisinde otelcilik deneyimi etkisinin önemi ortaya çıkmaktadır. Çalışanların oteldeki ve sektördeki deneyimlerinin artmasıyla birlikte duygusal emek kullanımında pek fazla duygusal uyumsuzluk yaşamadıkları ve gösterim kurallarının kendilerinde bir baskı oluşturmadan yüzeysel davranış veya derinlemesine davranış sergilemeden müşteri etkileşiminde kendi duygularıyla samimi davranış sergilediklerini söylemek mümkündür. 
İşletmelerin faaliyetlerinde etkili ve verimli olmaları, bu işletmelerde çalışan bireylerin yaptıkları katkılarla doğru orantılı olarak artmaktadır (Beğenirbaş, 2015). Bu doğrultuda otel işletmelerin belirli tecrübeye ve yaşa sahip çalışanları istihdam etmeleri gerek duygusal emek kullanımın olumsuz sonuçlarından daha az etkilenilmesine gerekse de hizmet kalitesinin arttırılmasına neden olacaktır. 


\section{KAYNAKÇA}

Anderson, Lindsey, (2014). "There Goes Another Little Chip of Your Heart: Exploring The İntersections of Communication, Emotional Labor, and Age". Unpublished Doctoral Dissertation, Purdue University West Lafayette, Indiana.

Ashforth, Blake E., and Humphrey Roland, H, (1993). "Emotional labor in service roles: The influence of identity". Academy of management review, 18(1), s.88-115.

Bağcı, Zubeyir ve Bursalı MohanYeliz, (2015). "Duygusal Emeğin İş Performansı Üzerindeki Etkisi: Denizli İlinde Hizmet Sektöründe Görgül Bir Araştırma”, Kafkas Üniversitesi İktisadi ve İdari Bilimler Fakültesi Dergisi, 6(10), s.71-75.

Bayram, Nuran, (2013). Yapısal Eşitlik Modellemesine Giriş Amos Uygulamaları, 2. bs.. Ezgi Kitabevi, Bursa.

Beğenirbaş, Memduh, (2015). "Psikolojik Sermayenin Çalışanların Duygu Gösterimleri ve İşe Yabancılaşmalarına Etkileri: Sağlık Sektöründe Bir Araştırma”. Süleyman Demirel Üniversitesi İktisadi ve İdari Bilimler Fakültesi Dergisi, 20(3), s.249-263.

Beğenirbaş, Memduh ve Çalışkan Abdullah, (2014). "Duygusal Emeğin İş Performansı ve İşten Ayrılma Niyetine Etkisinde Kişilerarası Çarpıklığın Aracılık Rolü”. Business and Economics Research Journal, 5(2), s.109-127.

Beğenirbaş, M., ve Meydan Cem Harun, (2012). "Duygusal Emeğin Örgütsel Vatandaşlık Davranışıyla İlişkisi: Öğretmenler Üzerinde Bir Araştırma”. İktisadi ve İdari Bilimler Fakültesi Dergisi, 14(3), 1-24.

Biron, Michal and March Van Veldhoven, (2012). "Emotional Labour İn Service Work: Psychological Flexibility And Emotion Regulation”. Human Relations, 65(10), s.1259-1282.

Brotheridge, Celeste M., and Grandey Alicia A, (2002). "Emotional Labor and Burnout: Comparing Two Perspectives of "People Work". Journal of Vocational Behavior,60(1), S.17-39.

Buckner, John E. (2012). Emotional Labor and Authentic Leadership, Unpublished Doctoral Dissertation, Louisiana Tech University, Ruston.

Chau, Samantha L., Dahling Jason J., Levy Paul E., and Diefendorff James M. (2009). “A Predictive Study of Emotional Labor and Turnover". Journal of Organizational Behavior, 30(8), s.1151-1163.

Cheung, Franchis Yeu-Lok., and Tang Catherina So-Kum, (2010). "Effects of Age, Gender, and Emotional Labor Strategies on Job Outcomes: Moderated Mediation Analyses". Applied Psychology: Health and Well-Being, 2(3), s.323-339.

Cheung, Franchis and Wu Anise M. S, (2013). "Emotional Labour and Successful Ageing in The Workplace Among Older Chinese Employees". Aging \& Society, 33(6), s.1036-1051.

Chu, Kay Hei-Lin,(2002). The Effects of Emotional Labor on Employee Work Outcomes. Unpublished Doctoral Dissertation, Virginia Polytechnic Institute and State University, Virginia

Chu, Kay Hei-Lin and Suzanne K. Murrmann, (2006). "Development and Validation of The Hospitality Emotional Labor Scale". Tourism Management, 27(6), s.1181-1191.

Cole, Graham, (2015). "Emotional Management in The Workplace: Age and Experience As Key İnfluences". Development and Learning in Organizations: An International Journal, 29(4), s.31-33.

Cote, Stéphane, and Laura M. Morgan, (2002). "A Longitudinal Analysis of The Association Between Emotion Regulation, Job Satisfaction, and Intentions To Quit”. Journal of Organizational Behavior, 23(8), s.947-962.

Cottingham, Marci D., Rebecca J. Erickson, and James M. Diefendorff, (2015). "Examining Men's Status Shield and Status Bonus: How Gender Frames The Emotional Labor and Job Satisfaction of Nurses". Sex Roles, 72(7-8), s.377-389.

Dahling, Jason J., and Luis A. Perez, (2010). "Older Worker, Different Actor? Linking Age and Emotional Labor Strategies". Personality and Individual Differences, 48(5), s.574-578.

Diefendorff, James M., Meredith H. Croyle, and Robin H. Gosserand. (2005). "The Dimensionality and Antecedents of Emotional Labor Strategies”. Journal of Vocational Behavior, 66(2), s.339-357.

Dursun, Bayram N, ve Aytaç, S. (2011). "Duygusal Emeğin İş Tatmini ve Tükenme Düzeyi Üzerine Etkisi”, 17. Ulusal Ergonomi Kongresi, s.14-16.

Enki, Ayşegül, (2019). Duygusal Emek ve İş Koliklik Arasındaki İlişki: Sağlık Çalışanları Üzerine Bir Araştırma, Yayımlanmamış Yüksek Lisans Tezi, Dumlupınar Üniversitesi, Kütahya.

Erickson, Rebecca J. (2005). "Why Emotion Work Matters: Sex, Gender, and The Division of Household Labor”. Journal of marriage and family, 67(2), s.337-351.

Erickson, J. R., and Christian Ritter. (2001). "Emotional Labor, Burnout, and İnauthenticity: Does Gender Matter?.” Social Psychology Quarterly, 64(2), s.146-163.

Ghalandari, Kamal, and Maryam Ghorbani Ghale Jogh, (2012). "The Effect of Emotional Labor Strategies (Surface Acting and Deep Acting) on Job Satisfaction and Job Burnout in Iranian Organizations: The Role of Emotional Intelligence". Interdisciplinary Journal of Research in Business, 1(12), s. 24-31.

Goodwin, R.E., Groth, M., and Frenkel, S.J., (2011). "Relationships Between Emotional Labor, Job Performance, And Turnover". Journal of Vocational Behavior, 79 (2), s.538- 548.

Grandey, Alicia A, (2000). "Emotional Regulation in The Workplace: A New Way To Conceptualize Emotional Labor". Journal of occupational health psychology, 5(1),s. 95.-110. 
Grandey, Alicia A, (2003). "When "The Show Must Go On": Surface Acting And Deep Acting As Determinants Of Emotional Exhaustion And Peer-Rated Service Delivery". Academy of management Journal, 46(1), s.86-96

Hochschild, Arlie Russell, (1990). Ideology and emotion management: A perspective and path for future research. In T. D. Kemper (Ed.), Research agendas in the sociology of emotions (pp.117-142). Albany, N. Y: State University of New York Press.

Hochschild, Arlie Russell,(1993). Preface. In S. Finemen (Ed.), Emotion in Organizations (p. xixiii). Newbury Park, CA: Sage Publication.

Hochschild, Arlie Russell, (1979). "Emotion Work, Feeling Rules, And Social Structure”. American journal of sociology, 85(3), s.551-575.

Hochschild, Arlie Russell, (2003). The Managed Heart: Commercialization Of Human Feeling. Berkeley: University of California.

Hochschild, Arlie Russell, 1983). The Managed Heart: Commercialization of Human Feeling. Berkeley, CA: University of California Press.

Kızanlıklı, Murat, (2014). Otel İşletmelerinde Duygusal Emek Öncüllerinin Belirlenmesine Yönelik Bir Araştırma.Yayımlanmamış Doktora Tezi,Gazi Üniversitesi,Ankara

Keleş, Yasin, (2014). Örgütsel Adaletin Duygusal Emek Üzerindeki Etkisi: Antalya'daki Beş Yıldızlı Otel İşletmelerinde Bir Araştırma. Yayımlanmamış Doktora Tezi, Gazi Üniversitesi, Ankara.

Kim, Hyun Jeong, (2008). "Hotel Service Providers' Emotional Labor: The Antecedents And Effects On Burnout". International Journal of Hospitality Management, 27(2), s.151-161.

Kruml, Susan M., and Deanna Geddes, (2000). "Exploring the dimensions of emotional labor: The heart of Hochschild's work". Management communication quarterly, 14(1), s.8-49.

Lee, Hyun Jung, (2016). "Effects of Public-Service Employee Age and Performance of Emotional Labor on Job Pride". Social Behavior and Personality: an international journal, 44(8), s.1339-1348.

Leidner, Robin, (1999). "Emotional Labor İn Service Work". The Annals of The American Academy of Political and Social Science, 561(1), s. 81-95.

Martínez-Iñigo, David, et al (2007). "Emotional Labour and Emotional Exhaustion:Interpersonal and İntrapersonal Mechanisms",Work \& Stress,21(1), s.30-47.

Meier, Kenneth J., Sharon H. Mastracci, and Kristin Wilson, (2006). "Gender And Emotional Labor İn Public Organizations: An Empirical Examination Of The Link To Performance”. Public Administration Review, 66(6), s.899-909.

Morris, J. Andrew, and Daniel C. Feldman, (1996). "The Dimensions, Antecedents, And Consequences Of Emotional Labor”. Academy Of Management Review, 21(4), 986-1010.

Savaş, Ahmet Cezmi, (2012). İlköğretim Okul Müdürlerinin Duygusal Zekâ ve Duygusal Emek Yeterliliklerinin Öğretmenlerin İş Doyumuna Etkisi. Yayımlanmamış Doktora Tezi, Gaziantep Üniversitesi, Gaziantep.

Schmidt, Klaus-Helmut, and Stefan Diestel, (2014). "Are Emotional Labour Strategies By Nurses Associated With Psychological Costs? A Cross-Sectional Survey.” International Journal of Nursing Studies, 51(11), s.1450-1461.

Seery, Brenda L., and Elizabeth A. Corrigall, (2009). "Emotional Labor: Links to Work Attitudes and Emotional Exhaustion". Journal of Managerial Psychology, 24(8), s.797-813.

Sezer, Aydın F, (2017). Banka Çalışanlarının Çatışma Yönetim Tarzı ile Duygusal Emek Harcama Düzeyleri Arasındaki İlişkilerin Araştırılması: Kars İli Örneği. Yayımlanmamış Yüksek Lisans Tezi. Kafkas Üniversitesi, Kars.

Tekin, Osman, (2018). Duygusal Emek ile İş Doyumu Arasındaki İlişkide Psikolojik Sermayenin Aracılık Rolü. Yayımlanmamış Yüksek Lisans Tezi, Erciyes Üniversitesi, Kayseri.

Schaubroeck, John, and James R. Jones, (2000). "Antecedents of Workplace Emotional Labor Dimensions And Moderators of Their Effects on Physical Symptoms". Journal of Organizational Behavior, 21, s.163-183.

Simon, Robin W., and Leda E. Nath, (2004). "Gender and Emotion in The United States: Do Men and Women Differ in Self-Reports of Feelings And Expressive Behavior?.” American Journal of Sociology, 109(5), s.1137-1176.

Walsh, Gianfranco, and Boris Bartikowski, (2013). "Employee Emotional Labour and Quitting İntentions: Moderating Effects of Gender And Age". European Journal Of Marketing, 47(8), s.1213-1237.

Wharton, Amy S, (1999). "The Psychosocial Consequences of Emotional Labor". The Annals of The American Academy of Political And Social Science, 561(1), s.158-176.

Wharton, Amy S., and Rebecca I. Erickson, (1993). "Managing Emotions on The Job and at Home: Understanding The Consequences of Multiple Emotional Roles". Academy of Management Review, 18(3), s.457-486.

Yang, Feng-Hua, and Chen-Chieh Chang, (2008). "Emotional Labour, Job Satisfaction and Organizational Commitment Amongst Clinical Nurses: A Questionnaire Survey”. International Journal of Nursing Studies, 45(6), s. 879-887. 